\title{
Phenol Removal from Aqueous Solutions by Electrocoagulation Technology Using Iron Electrodes: Effect of Some Variables
}

\author{
Mohammad Ali Zazouli, Mahmoud Taghavi* \\ Department of Environmental Health Engineering, Faculty of Health and Health Sciences Research Center, \\ Mazandaran University of Medical Sciences, Sari, Iran \\ Email: "Taghavim66@yahoo.com
}

Received July 16, 2012; revised September 8, 2012; accepted October 9, 2012

\begin{abstract}
The aim of this study was to determine the effect of electrocoagulation technology using iron electrodes on phenol removal in aqueous solutions. The removal of phenol was investigated in terms of various parameters, namely, current density, phenol and $\mathrm{NaCl}$ concentration, $\mathrm{pH}$, and alginic acid concentration. The results showed that the removal efficiency of phenol increased with increasing the current density, $\mathrm{pH}$ and $\mathrm{NaCl}$ concentration, whereas it was inversely associated with initial concentration of phenol and alginic acid concentration. According to the results, electrocoagulation is a promising process for treatment of wastewater containing high concentration of phenol.
\end{abstract}

Keywords: Phenol; Electrocoagulation; Water Treatment; Water Pollution

\section{Introduction}

One of the most prevalent forms of organic chemical pollutants in industrial wastewaters are Phenol and phenolic compounds [1]. High concentrations of phenol and phenolic compounds typically are found in aqueous effluents of oil refineries, petrochemical, ceramic, and steel plants, coal conversion processes, phenolic resin and pharmaceutical industries [1-4]. Since phenol and its derivatives are toxic and harmful to living organisms even at low concentrations, they are known as noxious pollutants [4]. The most widely used methods for phenol removal from aqueous solutions are adsorption, chemical oxidation, biological treatment, precipitation, distillation, solvent extraction, ion exchange, membrane processes, reverse osmosis, and electrochemical methods [2,4-6]. However, these methods have some problems such as high cost, low efficiency, and generation of toxic byproducts [6]. On the other hand, electrochemical methods have little or no harmful effects on the environment and electrochemical reactions are more or less independent of the conditions of the wastewater [6].

Electrocoagulation is an alternative technology for wastewater treatment in addition to its other conventional applications. The most important advantages of electrocoagulation compared with other conventional techniques are "in situ" delivery of reactive agents, no gen-

${ }^{*}$ Corresponding author. eration of secondary pollution, and compact equipment [7]. In this study, electrocoagulation using iron electrodes was conducted to investigate the removal of phenol from aqueous solutions.

\section{Material and Methods}

The phenol used in the experiments was provided from Merck Chemical Company; it was $98.5 \%$ pure. Furthermore, Alginate acid sodium salt from brown algae was purchased from Fluka Biochemical and the synthetic wastewater containing the phenol was prepared using distilled water. $\mathrm{pH}$ and conductivity were adjusted to a desired value using $0.1 \mathrm{M} \mathrm{HCl}$ and $\mathrm{NaOH}$. The electrolyte $(\mathrm{NaCl})$ concentration of $2 \mathrm{~g}$ was kept constant initially. The Plexiglas cell as electrolytic reactor having dimensions of $12 \mathrm{~cm} \times 12 \mathrm{~cm} \times 16 \mathrm{~cm}$ with a working volume of about $1.5 \mathrm{~L}$ was used to conduct the experiments, and a magnetic stirrer was applied for mixing $(200 \mathrm{rpm})$. Iron sheets with the dimensions of $0.10 \mathrm{~m} \times$ $0.10 \mathrm{~m} \times 0.002 \mathrm{~m}$ were also used as electrodes. Between two tests, electrolytic cell (including the electrodes) was cleaned with $15 \%(\mathrm{~W} / \mathrm{V})$ hydrochloric acid solution. The gap between the anode and cathode was $2 \mathrm{~cm}$. A Singleoutput Adjustable DC Power Supply (MPS-3005D) was used as the power supplier. Retention time, $\mathrm{pH}$, current density, and initial phenol, $\mathrm{NaCl}$, and alginic acid concentrations were selected as parameters. At different time intervals, the samples were taken from the reactor and 
centrifuged for $30 \mathrm{~min}$ at $4000 \mathrm{rpm}$ before analysis. Analyses were performed according to the standard methods for examination of water and wastewater [8]. Briefly, the concentrations of phenol were determined by spectrophotometer (Hach DR2800 spectrophotometer) according to the analysis of the color resulted from the reaction of phenol with 4-aminoantipyrine at $500 \mathrm{~nm}$.

\section{Result and Discussion}

\subsection{Effect of $\mathbf{p H}$}

In this study, the phenol removal efficiency was determined in the $\mathrm{pH}$ range from 3 to 11 . Figure 1 shows the influence of solution $\mathrm{pH}$ on phenol removal. It shows that the phenol removal efficiency increased with $\mathrm{pH}$ until it reached to 7, and after this point, further increase of $\mathrm{pH}$, the removal efficiency decreased. Maximum removal occurred at $\mathrm{pH} 7$ value, thus $\mathrm{pH}=7$ was the optimum $\mathrm{pH}$. In agreement with our findings, Yavuz et al. reported that $\mathrm{pH}$ adjustment is not necessary because the most appropriate results are achieved when initial $\mathrm{pH}$ was 7 [9]. The kinetics of $\mathrm{Fe}^{2+}$ conversion to $\mathrm{Fe}^{3+}$ are strongly affected by the $\mathrm{pH}$; the surface charge of the coagulating particle also varies with $\mathrm{pH}$. In general, at lower and higher $\mathrm{pH} \mathrm{Fe}$ is increasingly soluble. At lower $\mathrm{pH}$ the protons in the solution are reduced to $\mathrm{H}_{2}$ at the cathode and the same proportion of hydroxide ions cannot be produced. At lower $\mathrm{pH}, \mathrm{Fe}(\mathrm{OH})^{2+}$ and $\mathrm{Fe}(\mathrm{OH})_{2}^{+}$ were produced which are disadvantageous for phenol precipitation [10].

\subsection{Effect of Current Density}

The supply of current density to the electrocoagulation system is a determining factor for the amount of $\mathrm{Fe}^{2+}$ ions released from the electrodes. To investigate the effect of current density on metal removal, electrocoagula-

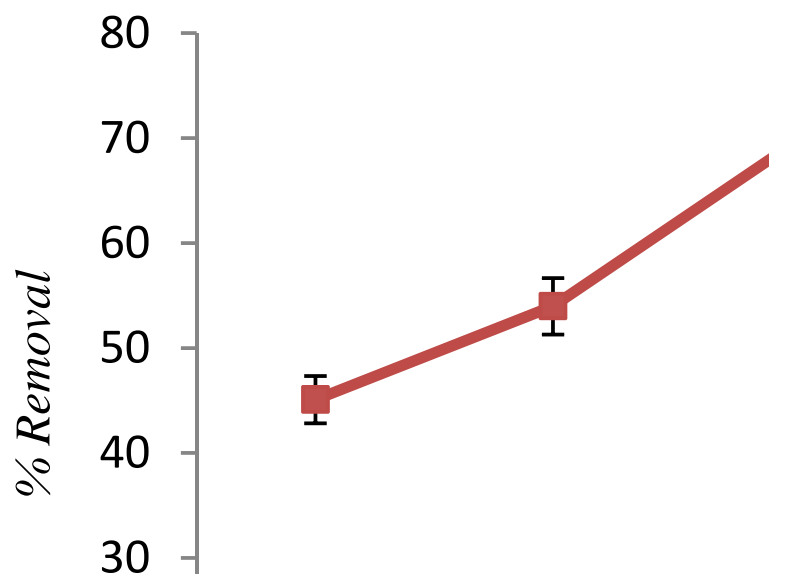

Figure 1. The effect of $\mathrm{pH}$ on phenol removal by electrocoagulation (c.d $=10 \mathrm{~mA} / \mathrm{cm}^{2}, \mathrm{NaCl}=2 \mathrm{~g} / \mathrm{L}$, phenol $=100$ $\mathrm{mg} / \mathrm{L}, \mathrm{T}=20^{\circ} \mathrm{C}$, time $\left.=60 \mathrm{~min}\right)$. tion process was carried out using various current densities varying from 5 to $25 \mathrm{~A}$ at $\mathrm{pH} 7$. Figure 2 shows the effect of current density on phenol removal in the electrocoagulation process. As shown in this Fig, the removal rate of phenol increased with increasing current density, and the highest current density $\left(25 \mathrm{~mA} / \mathrm{cm}^{2}\right)$ had the maximum removal efficiency. That is because increasing the current density caused higher coagulant dissolution, and $\mathrm{OH}^{-}$production resulted in a more efficient and faster removal [11]. A large current density means a small electrocoagulation unit. However, when so large a current density is used, there is a high chance of wasting electrical energy in heating up the water. More importantly, it would result in a significant decrease in current efficiency [12]. Therefore, to ensure a high current efficiency, the current density selection should be made along with including other operating parameters such as $\mathrm{pH}$ and temperature as well as flow rate.

\subsection{Effect of Initial Phenol Concentration}

Figure 3 depicts the effect of initial phenol concentration on the efficiency of phenol removal. As shown in Figure 3 , increasing the concentration of phenol led to decreasing the removal efficiency from $91 \%$ to $70.1 \%$. This is attributed to the fact that at a constant current density, the same number of iron ions passes to the solution at dif-

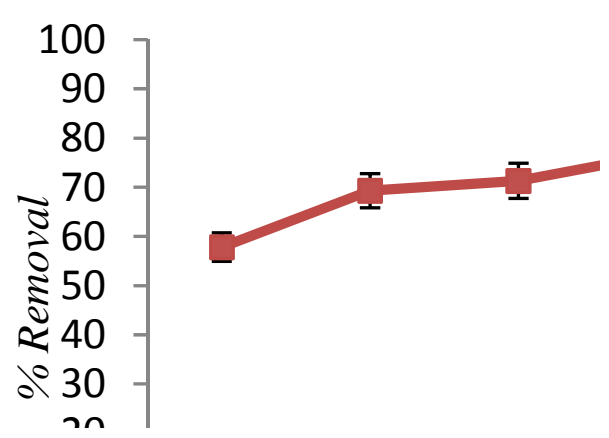

Figure 2. The effect of current density on phenol removal by electrocoagulation $(\mathrm{pH}=7, \mathrm{NaCl}=2 \mathrm{~g} / \mathrm{L}$, phenol $=100$ $\mathrm{mg} / \mathrm{L}, \mathrm{T}=20^{\circ} \mathrm{C}$, time $\left.=60 \mathrm{~min}\right)$.

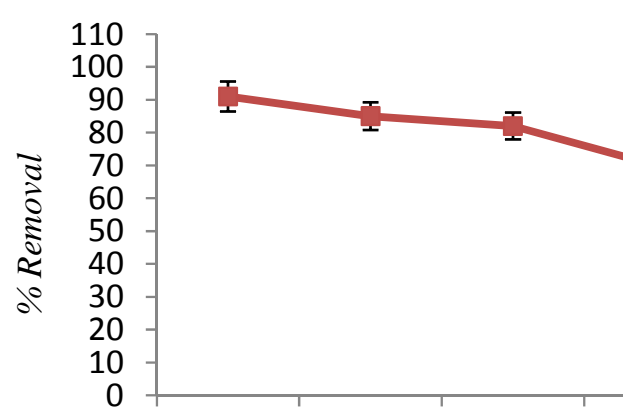

Figure 3. The effect of initial phenol concentration on phenol removal by electrocoagulation $\left(\mathrm{pH}=7, \mathrm{c.d}=25 \mathrm{~mA} / \mathrm{cm}^{2}\right.$, $\mathrm{NaCl}=2 \mathrm{~g} / \mathrm{L}, \mathrm{T}=20^{\circ} \mathrm{C}$, time $\left.=60 \mathrm{~min}\right)$. 
ferent phenol concentrations. As a result, the formed amount of complex iron hydroxide was insufficient to coagulate the greater number of phenol molecules at higher phenol concentrations [6]. The results of this study are consistent with the result of the research conducted by Yusuf Yavuz and Savas Koparal on electrochemical oxidation of phenol in a parallel plate reactor using ruthenium mixed metal oxide electrode [9].

\subsection{Effect of $\mathrm{NaCl}$ Concentration}

In all experiments, background electrolyte solution contains $\mathrm{NaCl}$ with varying conductivity because it is easily found in water and wastewater. Figure 4 clearly shows that the phenol removal increases as the $\mathrm{NaCl}$ concentration of the feed solution raises from 0.5 to $3 \mathrm{~g} / \mathrm{L}$. As shown in Figure 4, the efficiency of phenol removal increased from $55.5 \%$ to $86.6 \%$ after 60 min of electrocoagulation. The results reported by Abdelwahab et al. [6] regarding the effect of $\mathrm{NaCl}$ concentration are compatible with the result of the present work. It's been confirmed that the existence of carbonate or sulfate ions would lead to the precipitation of $\mathrm{Ca}^{2+}$ or $\mathrm{Mg}^{2+}$ ions that form an insulating layer on the surface of the electrodes. This insulating layer increases the potential between electrodes which in turn decreases the current efficiency significantly. The addition of $\mathrm{NaCl}$ results in chloride ions which in turn could significantly reduce the adverse effect of other anions $\left(\mathrm{HCO}_{3}^{-}, \mathrm{SO}_{4}^{2-}\right)$. In addition, increase in chloride anions leads to a rise in conductivity which in turn decreases the power consumption [12].

\subsection{Effect of Alginic Acid Concentration}

Effect of natural organic matter (NOM) was investigated by introducing alginate at three different concentrations $(5,10$ and $15 \mathrm{mg} / \mathrm{L})$ into the feed solutions. To examine the effect of alginic acid on the phenol removal efficiency, while other parameters were kept constant, a

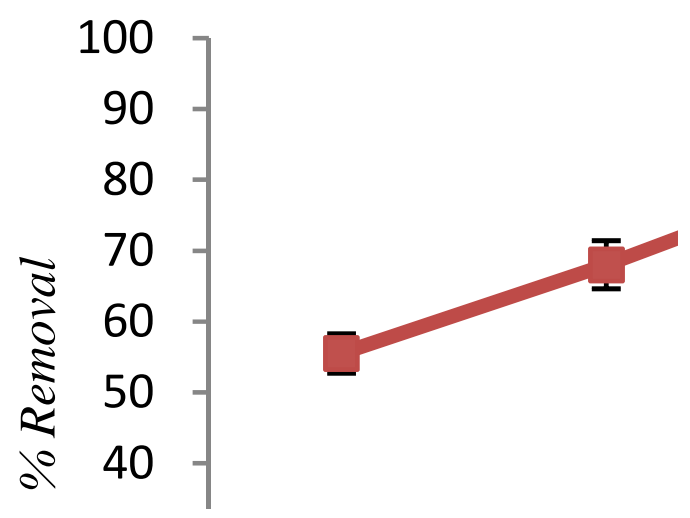

Figure 4. The effect of $\mathrm{NaCl}$ concentration on phenol removal by electrocoagulation ( $\mathrm{pH}=7$, c.d $=25 \mathrm{~mA} / \mathrm{cm}^{2}$, phe$\mathrm{nol}=100 \mathrm{mg} / \mathrm{L}, \mathrm{T}=20^{\circ} \mathrm{C}$, time $\left.=60 \mathrm{~min}\right)$. nominal value of alginic acid concentration ranging from 5 to $15 \mathrm{~g} / \mathrm{L}$ was added to synthetic aqueous solutions. Figure 5 illustrates the influence of alginic acid concentration on phenol removal. It was observed that increasing alginic acid concentrations decreased the removal efficiency of phenol. It seems that one reason can be negative charge of the alginic acid. $\mathrm{pH}_{\mathrm{zpc}}$ is defined as the $\mathrm{pH}$ at which the total surface charge becomes zero. It means that at an upper $\mathrm{pH}$ range than $\mathrm{pH}_{\mathrm{zpc}}$, the surface of biomass shows a negative charge. Jeon et al. were determined the $\mathrm{pH}_{\text {zpc }}$ of alginic acid about 2.83 [13]. While, in this step of experiment, the $\mathrm{pH}$ of solution was 7. So, the surface charge of the alginic acid will negative, and therefore it was attract small part of the metal ions produced. Further, Alginic acid has been shown to be effecttive at removing many cationic metals from solution $[14,15]$. As a result, increasing the amount of alginic acid will decrease efficiency of phenol removal by electrocoagulation.

\section{Conclusion}

In the present work, the efficiency of electrocoagulation process for the phenol removal has been investigated. This investigation has led to the following results. Firstly, the phenol removal efficiency increased with the $\mathrm{NaCl}$ concentration and current density. Secondly, the removal efficiency of phenol was inversely associated with initial concentration of phenol and alginic acid concentration as natural organic matter. Finally, the optimum $\mathrm{pH}$ for phenol removal by the electrocoagulation was 7 . In addition, based on the results of this study, the phenol removal by electrocoagulation using iron electrode seems to be a very efficient method for treatment of wastewaters containing high concentration of phenol.

\section{Acknowledgements}

The authors would like to express their thanks to the

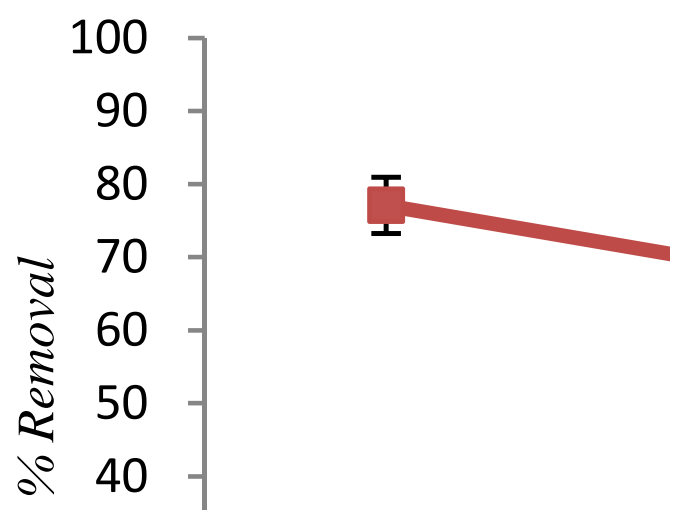

Figure 5. The effect of alginic acid concentration on phenol removal by electrocoagulation $\left(\mathrm{pH}=7, \mathrm{c.d}=25 \mathrm{~mA} / \mathrm{cm}^{2}\right.$, $\mathrm{NaCl}=2 \mathrm{~g} / \mathrm{L}$, phenol $=100 \mathrm{mg} / \mathrm{L}, \mathrm{T}=20^{\circ} \mathrm{C}$, time $\left.=60 \mathrm{~min}\right)$. 
laboratory staff of the Department of Environmental Health Engineering, Faculty of Health, for their collaboration and to Health Sciences Research Center and the Research Deputy of Mazandaran University of Medical Sciences for the financial support of this study (Project No: 89-140).

\section{REFERENCES}

[1] A. Bodalo, J. L. Gomez, M. Gomez, G. Leon, A. M. Hidalgo and M. A. Ruiz, "Phenol Removal from Water by Hybrid Processes: Study of the Membrane Process Step," Desalination, Vol. 223, No. 1-3, 2008, pp. 323-329. doi:10.1016/i.desal.2007.01.219

[2] L. A. Rodriguesa, M. L. C. P. D. Silvab, M. O. Alvarez-Mendesc, A. D. R. Coutinhoc and G. P. Thima, "Phenol Removal from Aqueous Solution by Activated Carbon Produced from Avocado Kernel Seeds," Chemical Engineering Journal, Vol. 174, 2011, pp. 49-57.

[3] M. Caetano, C. Valderrama, A. Farran and J. L. Cortina, "Phenol Removal from Aqueous Solution by Adsorption and Ion Exchange Mechanisms onto Polymeric Resins," Journal of Colloid and Interface Science, Vol. 388, No. 2, 2009, pp. 402-409. doi:10.1016/j.jcis.2009.06.062

[4] H. B. Senturka, D. Ozdesa, A. Gundogdua, C. Durana and M. Soylakb, "Removal of Phenol from Aqueous Solutions by Adsorption onto Organomodified Tirebolu Bentonite: Equilibrium, Kinetic and Thermodynamic Study," Journal of Hazardous Materials, Vol. 172, No. 1, 2009, pp. 353-362. doi:10.1016/j.jhazmat.2009.07.019

[5] R. Aravindhan, J. R. Rao and B. U. Nair, "Application of a Chemically Modified Green Macro Alga as a Biosorbent for Phenol Removal," Journal of Environmental Management, Vol. 90, No. 5, 2009, pp. 1877-1883. doi:10.1016/j.jenvman.2008.12.005

[6] O. Abdelwahaba, N. K. Aminb and E.-S. Z. El-Ashtoukhy, "Electrochemical Removal of Phenol from Oil Refinery Wastewater," Journal of Hazardous Materials, Vol. 163, No. 2-3, 2009, pp. 711-716. doi:10.1016/j.jhazmat.2008.07.016

[7] M. Saleem, A. A. Bukhari and M. N. Akram, "Electrocoagulation for the Treatment of Wastewater for Reuse in Irrigation and Plantation," Journal of Basic and Applied Sciences, Vol. 7, No. 1, 2011, pp. 11-20.

[8] APHA, AWWA and WEF, "Standard Methods for the Examination of Water and Wastewater," American Public Health Association American Water Work Association Water Environment Federation, 1999.

[9] Y. Yavuz and A. S. Koparal, "Electrochemical Oxidation of Phenol in a Parallel Plate Reactor Using Ruthenium Mixed Metal Oxide Electrode," Journal of Hazardous Materials B, Vol. 136, No. 2, 2006, pp. 296-302. doi:10.1016/j.jhazmat.2005.12.018

[10] Ä. A. Åžengil and M. Ãzacar, "The Decolorization of c.I. Reactive Black 5 in Aqueous Solution by Electrocoagulation Using Sacrificial Iron Electrodes," Journal of Hazardous Materials, Vol. 161, No. 2-3, 2009, pp. 1369-1376. doi:10.1016/j.jhazmat.2008.04.100

[11] F. Akbal and S. Camc1, "Treatment of Metal Plating Wastewater by Electrocoagulation," Environmental Progress \& Sustainable Energy, 2011, in press.

[12] G. Chen, "Electrochemical Technologies in Wastewater Treatment," Separation and Purification Technology, Vol. 38, No. 1, 2004, pp. 11-41. doi:10.1016/j.seppur.2003.10.006

[13] C. Jeon, J. Y. Park and Y. J. Yoo, "Characteristics of Metal Removal Using Carboxylated Alginic Acid," Water Research, Vol. 36, No. 7, 2002, pp. 1814-1824. doi:10.1016/S0043-1354(01)00389-X

[14] J. H. Min and J. G. Hering, "Arsenate Sorption by Fe(iii)-Doped Alginate Gels," Water Research, Vol. 32, No. 5, 1998, pp. 1544-1552. doi:10.1016/S0043-1354(97)00349-7

[15] M. A. Zazouli, M. Taghavi and E. Bazrafshan, "Influences of Solution Chemistry on Phenol Removal from Aqueous Environments by Electrocoagulation Process Using Aluminum Electrodes," Journal of Health Scope, Vol. 1, No. 2, 2012. pp. 65-70. doi:10.5812/jhs.5462 